\title{
GENERATION AND EVALUATION OF RADARGRAMMETRIC DEM FROM RADARSAT-1 STANDARD IMAGES IN LOW RELIEF AREA IN THE AMAZON COASTAL PLAIN
}

\author{
Edson Adjair de Souza Pereira',2, Pedro Walfir M. Souza-Filho2,3, \\ Waldir R. Paradella ${ }^{4}$ and Wilson da Rocha Nascimento $\mathrm{Jr}^{2}$
}

\begin{abstract}
The generation of digital elevation models (DEMs) from the Standard imaging mode of RADARSAT-1 stereo-images was investigated to evaluate the viability of producing 1:100,000 scale altimetric maps in areas with a low topographic relief on the Brazilian Amazon coastal plain. Absolute DEMs were generated using RADARSAT-1 Standard stereopairs (S2Asc/S1Des, S6Des/S1Des, and S7Asc/S6Des) with ground control points collected using a Differential Global Positioning system. The geometric modeling for the DEM extractions was based on the "RADARSAT Specific Model" from the OrthoEngine Satellite Edition of the PCI Geomatica software; this model is an automated matching solution that considers the slant range distances from sensors and terrain. Thirteen independent control points were used to validate the accuracy of the absolute DEM. Only the S2Asc/S1Des pair was effective in highlighting depth information, which was a result of the pair's intermediate intersection angle $\left(47^{\circ}\right)$ and higher vertical parallax ratio (4.31). Therefore, RADARSAT-1 Standard images are a useful alternative for generating absolute DEM at the scale of 1:100,000 in cartographic gap areas on the Amazon coastal plain.
\end{abstract}

Keywords: digital elevation model, stereoscopy, RADARSAT-1, Amazon, Brazil.

RESUMO. A geração de modelos digitais de elevação (MDEs) a partir de pares estereoscópicos RADARSAT-1 modo Standard foi empregada com 0 objetivo de avaliar a produção de mapa altimétrico na escala de 1:100.000 em uma área de baixo relevo na planície costeira amazônica. MDEs absolutos foram gerados usando pares estereoscópicos RADARSAT-1 Standard (S2Asc/S1Des, S6Des/S1Des e S7Asc/S6Des) com pontos de controle do terreno coletados usando-se um sistema de posicionamento global diferencial. 0 modelamento geométrico para extração do MDE foi baseado no "Modelo Específico para o RADARSAT", do programa PCI Geomatica, através do cálculo que maximiza o coeficiente de correlação e leva em consideração as distâncias no alcance inclinado entre 0 sensor e 0 terreno. Para a validação do MDE absoluto foram usados 13 pontos de controle independentes. Apenas o par S2Asc/S1Des foi eficaz no realce da informação de profundidade, devido aos ângulos de intersecção intermediários $\left(47^{\circ}\right)$, mas principalmente, devido a maior razão da paralaxe vertical observada $(4,31)$. Portanto, as imagens RADARSAT-1 Standard representam uma ótima alternativa para a produção de MDEs absolutos na escala de 1:100.000 em áreas com vazios cartográficos na planície costeira amazônica.

Palavras-chave: modelo digital de elevação, estereoscopia, RADARSAT-1, Amazônia, Brasil.

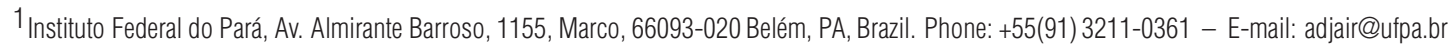

2 Universidade Federal do Pará, Laboratório de Análise de Imagens do Trópico Úmido, Instituto de Geociências, Av. Augusto Correa, 1, Cidade Universitária, P.0. Box 8608, 66075-900 Belém, PA, Brazil. Phone: +55(91) 3201-8009; Fax: +55(91) 3201-7478 - E-mail: walfir@ufpa.br

3 Vale Institute of Technology, Rua Boaventura da Silva, 955, 66055-090 Belém, PA, Brazil - E-mail: pedro.martins.souza@itv.org

${ }^{4}$ Instituto Nacional de Pesquisas Espaciais, Divisão de Processamento de Imagem, P.0. Box 515, 12227-010 São José dos Campos, SP, Brazil

- E-mail: waldir@|tid.inpe.br
} 


\section{INTRODUCTION}

The generation of topographic maps in coastal areas is a significant challenge, especially in humid tropical areas where weather conditions hinder the acquisition of images without cloud cover by remote optical sensors. Moreover, the dense canopy of mangrove forests on the coastal plain prevents the collection of ground control points (GCPs), which makes it difficult to generate digital elevation models (DEMs). Estimates by the Brazilian Institute of Geography and Statistics (Instituto Brasileiro de Geografia e Estatística - IBGE, 2001) indicate that only 35\% of the Amazon coastal plain is mapped at a 1:100,000 scale (Fig. 1). Currently, synthetic aperture radar (SAR) images are available; however, their use is limited because there are not enough qualified technicians to process the SAR data. Nevertheless, the data are available, and processing techniques exist, which makes SAR images a useful alternative for mapping semi-detailed scales in the Amazon region (Paradella et al., 2003, 2005).

Synthetic aperture radar (SAR) systems (ERS-1, JERS-1, RADARSAT-1 and -2, ENVISAT, ALOS, TerraSAR and COSMO Sky-Med) have provided data for the development of cartographic applications with SAR data (Oliveira et al., 2011a, 2011b). Four methods have been used in the generation of DEMs using SAR data: clinometry, stereoscopy or radargrammetry, interferometry and polarimetry (Toutin \& Gray, 2000). In this study, orbital radargrammetry with ascending and descending lateral looks is used. In the first case, the ground is illuminated under the same look angle and azimuth in both scenes, and the only variation is in the angle of incidence. For the opposite-side stereoscopy, the same area is obliquely illuminated in opposite directions. In the case of RADARSAT-1, this illumination occurs both in the ascending and descending orbits with different illumination azimuths.

It is important to emphasize that same-side stereoscopy favors the radiometric correlation between the stereopair images, whereas opposite-side stereoscopy leads to geometric and radiometric differences between the images in the extremes (Fullerton et al., 1986; Toutin, 1996). Thus, in an ideal same-side stereoscopic pair, the images must be similar so that there is a strong radiometric correlation that results in good stereoscopic visibility. The ideal opposite-side stereoscopic pair, however, consists of images with the most different geometries possible to present large parallaxes (Toutin, 1996).

Thus, radargrammetry that uses orbital SAR images is an alternative for topographic mapping on the Amazon coastal plain. The objective of this study was to generate and evaluate DEMs from RADARSAT-1 stereopairs in Standard imaging mode for the production of altimetric maps at the 1:100,000 scale for car- tographic gaps in low relief areas in the Amazon coastal zone (Fig. 1). Despite the existence of elevation data from the shuttle radar topographic mission (SRTM) (Rabus et al., 2003), the technique for generating DEMs from RADARSAT images must be mastered to produce DEMs from high spatial resolution data, such as RADARSAT-2 and TerraSAR- $X$, because such data provide images with 1 to $3 \mathrm{~m}$ spatial resolution and elevation accuracy between 3 and 10 meters (Van der Sanden \& Ross, 2004), which enable the extraction of ideal maps for low relief areas with smaller contouring equidistance.

\section{STUDY AREA}

The study area is located eastward of the Amazon River mouth in the state of Pará, and it comprises an extensive coastline of macrotidal mangroves in the Amazon (Nascimento Jr. et al., 2013). The area is characterized by a low relief (0 to $200 \mathrm{~m}$ ), broad coastal plain (up to $70 \mathrm{~km}$ wide) and extensive adjacent continental platform ( $\sim 200 \mathrm{~km}$ wide) that is extremely irregular and indented with a low-gradient coast (Souza Filho, 2005).

Souza Filho \& El-Robrini (2000) divided the geomorphology of the study area into three morphological domains: (1) alluvial plain with fluvial channel, levees and floodplain; (2) estuarine plain with an estuarine channel subdivided into an estuarine funnel segment, straight segment, meandering segment, upstream channel, tidal channel and floodplain; and (3) coastal plain with salt marsh (inner and outer), tidal plain (supratidal mangroves, intertidal mangroves and sand flats with tidal shoals), coastal dunes and beaches. The climate is characterized by a rainy season from December to May that is followed by a dry season from June to November, and the annual average rainfall is 2,500 $\mathrm{mm}$ (Moraes et al., 2005). There is a $5 \mathrm{~m}$ variation relative to the mean tide level in a semidiurnal cycle (Monteiro et al., 2009). Wetland zones near major river and estuarine systems are characterized by large tida ranges and an ample supply of sediments, which create intertidal mudbanks colonized by mangrove forests that are frequently inundated by tides (Souza Filho et al., 2003; Pereira et al., 2012).

\section{MATERIALS AND METHODS}

\section{RADARSAT dataset for generation of DEM}

RADARSAT-1 is an Earth observation satellite developed by the Canadian Space Agency that operates in the microwave frequency (C-band) with a frequency of $5.3 \mathrm{GHz}$ or $5.6 \mathrm{~cm}$ wavelength. The satellite transmits and receives horizontal polarized energy $(\mathrm{HH})$ with a look direction to the right of the orbit in both the ascending (Asc) and descending (Des) orbit (RADARSAT International, 1995). 


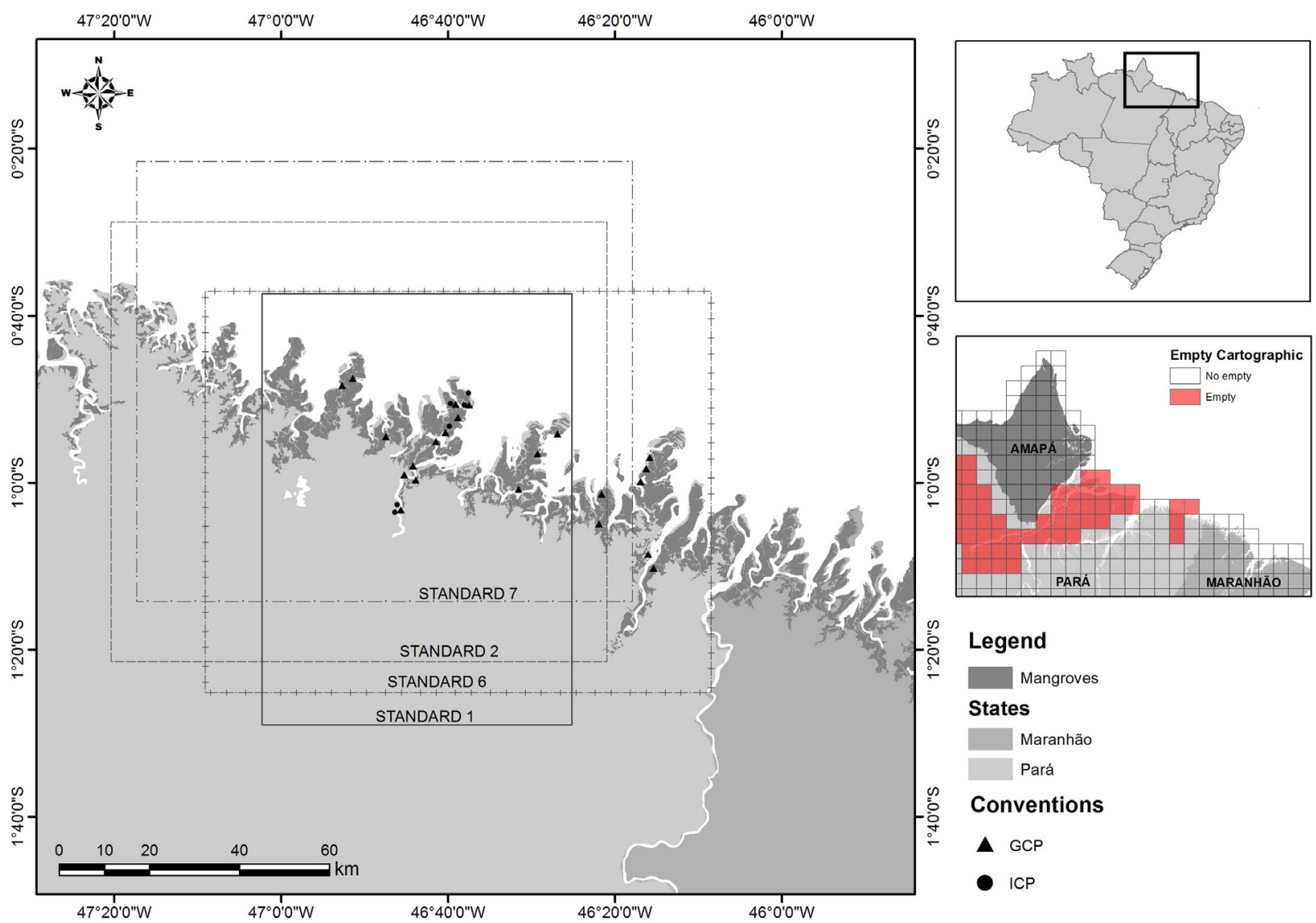

Figure 1 - Location of the study area showing the planialtimetric sheets produced by IBGE at a 1:100,000 scale for the coastal region of the states of Amapá, Pará and Maranhão. Note the position of the RADARSAT-1 Standard images used for the generation of digital elevation models.

Table 1 - Characteristics of RADARSAT-1 Standard images.

\begin{tabular}{|c|c|c|c|c|c|c|}
\hline Image & $\begin{array}{c}\text { Data of } \\
\text { acquisition }\end{array}$ & Orbit & $\begin{array}{c}\text { Incidence } \\
\text { angle }\end{array}$ & Swatch & $\begin{array}{c}\text { Spatial resolution } \\
\text { (Range } \times \text { Azimuth) }\end{array}$ & $\begin{array}{c}\text { Tide } \\
\text { condition }\end{array}$ \\
\hline Standard 1 & $05 / 19 / 2003$ & Descending & $20^{\circ}-27^{\circ}$ & $100 \mathrm{~km}$ & $26 \times 27 \mathrm{~m}$ & Low tide \\
Standard 2 & $05 / 09 / 2003$ & Ascending & $24^{\circ}-31^{\circ}$ & $100 \mathrm{~km}$ & $22 \times 27 \mathrm{~m}$ & High tide \\
Standard 6 & $05 / 16 / 2003$ & Descending & $41^{\circ}-46^{\circ}$ & $100 \mathrm{~km}$ & $22 \times 27 \mathrm{~m}$ & Ebb tide \\
Standard 7 & $05 / 19 / 2003$ & Ascending & $45^{\circ}-49^{\circ}$ & $100 \mathrm{~km}$ & $22 \times 27 \mathrm{~m}$ & Ebb tide \\
\hline
\end{tabular}

RADARSAT-1 Standard images were acquired between May 09 and 19, 2003 in Standard 1 (S1), Standard 2 (S2), Standard 6 (S6) and Standard 7 (S7) modes to minimize possible variations in the terrain backscatter responses induced by atmospheric and/or anthropogenic activities (e.g., land use and deforestation). Table 1 summarizes the characteristics of the images used in this study. Four pairs of images were generated: (1) S6Des/S1Des; (2) S7Asc/S6Des; (3) S2Asc/S1Des and (4) S7Asc/S2Asc; to be used for generation of digital elevation models (Fig. 2).

\section{Radar stereoscopy}

Orbital radar stereoscopy (radargrammetry) is a function of two photogrammetric indicators: (a) stereoscopic parallax, which is related to the apparent shifting of objects when viewed from different positions; and (b) stereoscopic intersection angle, which is measured between the lines of sight of the sensor at a certain point on the ground and obtained from a stereopair. Toutin (1997) proposed the vertical parallax ratio (VPR) to estimate the optimal configuration of the stereopairs of SAR images. The VPR is 


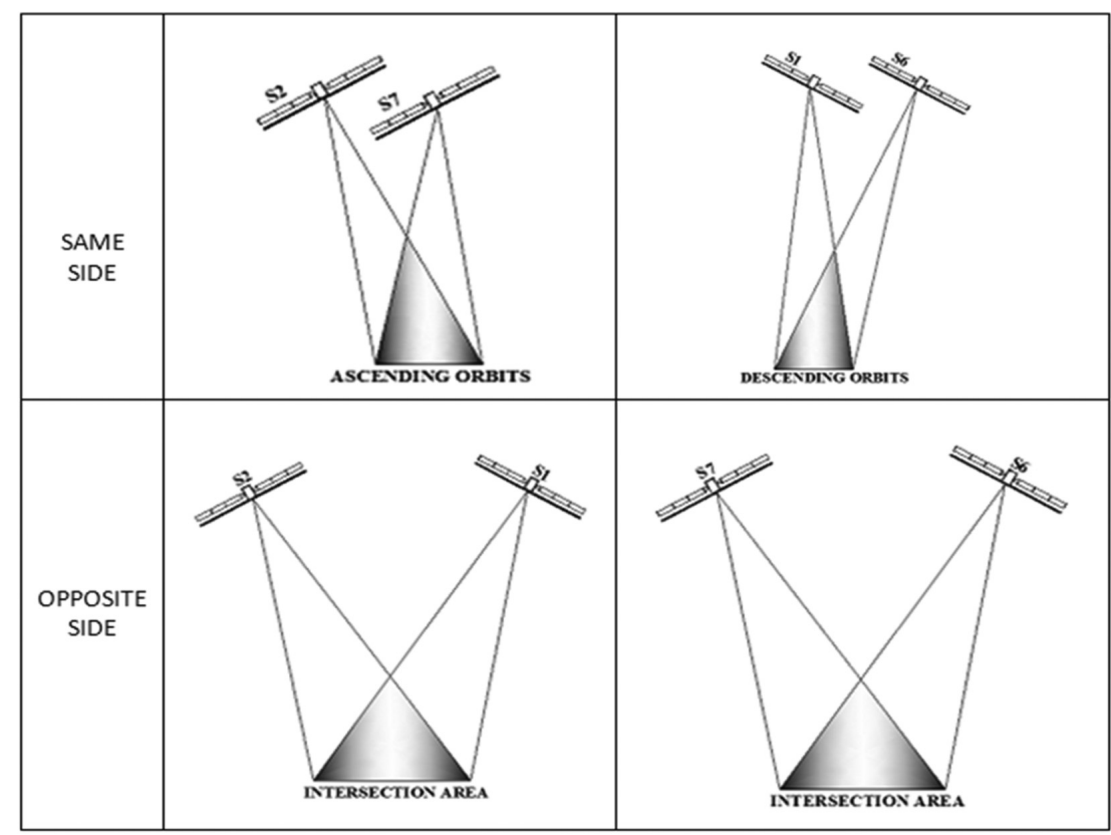

Figure 2 - Possible combinations of the stereopairs of RADARSAT-1 Standard images used in this study.

defined as follows:

$$
\mathrm{VPR}=p / h=[\cot R-\cot L]
$$

where $p$ is the elevation parallax, $h$ is the target elevation, and $\cot R$ and $\cot L$ are the cotangents of the look angles of the images in the pair (right and left look, respectively). Disregarding the curvature of the Earth, the look angle is equal to the angle of incidence (in the case of a flat relief). Thus, larger VPRs provide improved 3D perception and a greater potential for deriving altimetry.

\section{Collection of ground control points (GCPs)}

The collection of GCPs was conducted with two dual frequency geodetic receivers (Differential Global Positioning System, DGPS) Z-Xtreme model. A total of 33 static measurements were collected between July and August 2005 (see locations in Fig. 1). The differential calculation to correct the position of the GCPs was based on the Belém station, which belongs to the Brazilian Network of Continuous Monitoring (Rede Brasileira de Monitoramento Contínuo - RBMC) of the IBGE. The data were corrected for tropospheric effects, and the orthometric altitudes were determined with the use of the DGPS leveling associated with the Brazilian geoid model, whose geoid undulation was obtained with MAPGEO 2004 software (Mapa Geoidal do Brasil, 2004), which was made available by the IBGE. The geographic coordinates were transformed according to the SAD-69 datum (South Ameri- can Datum 1969) because the RBMC stores its data according to this datum. To validate the accuracy of the absolute DEMs were generated 13 independent check points (ICPS).

Maximum errors with a probability of $68.3 \%$ (1s) were calculated for the estimated positions, which were $31 \mathrm{~cm}$ for the northing value, $55 \mathrm{~cm}$ for the easting value and $30 \mathrm{~cm}$ for the ellipsoid height. All the coordinates conform to Universal Transverse Mercator (UTM) projections and Datum SAD-69 (Table 2).

\section{Methodology for the generation of DEMs}

The steps for generating radargrammetry DEMs are systematized in Figure 3. Of the 33 collected GCPs, 28 were selected to verify the scale; of these, 13 were used to validate the accuracy of the absolute DEM that was generated. The 5 remaining GCPs were used in the orthorectification process of the RADARSAT- 1 images because they were the only points collected in the field that were identifiable in the images. To improve the accuracy of the orthorectification, 15 additional GCPs were extracted from an orthorectified Landsat TM 5 image, which was available at the Global Land Cover Facility Project website (http://glcf.umiacs.umd.edu). The procedure for obtaining errors after orthorectification of the RADARSAT-1 images is shown in Table 3. The total residual error and root mean square error (RMSE) of each scene are shown in Table 4. The equation used to calculate the RMSE is presented below:

$$
\operatorname{RMSE}=\sqrt{\Sigma(Z i-Z t) 2 / \mathrm{n}}
$$


Table 2 - Ground control point (GCP) collected with differential GPS to adjust and validation of digital terrain model from radargrammetry of RADARSAT-1 images. Projection UTM, Zone 23 South and Datum SAD-69.

\begin{tabular}{|c|c|c|c|c|c|c|}
\hline GCP & $\begin{array}{l}\text { UTM N } \\
\text { SAD-69 }\end{array}$ & $\begin{array}{l}\text { UTM E } \\
\text { SAD-69 }\end{array}$ & $\begin{array}{c}\text { Orthometric } \\
\text { altitude } \\
H(m)\end{array}$ & $\begin{array}{l}\text { Error in } \\
\text { North } \\
\text { (m) }\end{array}$ & $\begin{array}{l}\text { Error in } \\
\text { East } \\
\text { (m) }\end{array}$ & $\begin{array}{c}\text { Error in } \\
\text { altitude } \\
\text { (m) }\end{array}$ \\
\hline P01 & 9907947.14004 & 321738.36544 & 5.41 & 0.087 & 0.337 & 0.177 \\
\hline P02 & 9907977.84252 & 321707.43421 & 5.52 & 0.036 & 0.124 & 0.082 \\
\hline P03 & 9908008.55756 & 321707.42173 & 6.94 & 0.038 & 0.289 & 0.089 \\
\hline P04 & 9908039.24750 & 321645.57175 & 7.60 & 0.039 & 0.106 & 0.076 \\
\hline P05 & 9908131.38012 & 321614.61557 & 6.74 & 0.064 & 0.151 & 0.103 \\
\hline P06 & 9906439.97905 & 316668.26844 & 5.13 & 0.053 & 0.148 & 0.084 \\
\hline P07 & 9906687.36339 & 320625.80638 & 6.05 & 0.055 & 0.147 & 0.117 \\
\hline P08 & 9908346.34796 & 321521.77204 & 6.30 & 0.110 & 0.265 & 0.192 \\
\hline P09 & 9908407.77810 & 321521.74716 & 5.57 & 0.043 & 0.118 & 0.067 \\
\hline P10 & 9908469.19573 & 321490.80350 & 6.26 & 0.075 & 0.162 & 0.105 \\
\hline P11 & 9908530.61338 & 321459.85983 & 5.89 & 0.088 & 0.194 & 0.139 \\
\hline P12 & 9908530.58837 & 321398.02218 & 4.61 & 0.083 & 0.265 & 0.196 \\
\hline P13 & 9908592.00604 & 321367.07850 & 6.14 & 0.060 & 0.205 & 0.143 \\
\hline P14 & 9908622.72113 & 321367.06608 & 4.67 & 0.314 & 0.558 & 0.301 \\
\hline P15 & 9908653.42373 & 321336.13482 & 6.92 & 0.061 & 0.179 & 0.111 \\
\hline P16 & 9908684.12633 & 321305.20356 & 6.74 & 0.077 & 0.291 & 0.148 \\
\hline P17 & 9908745.54405 & 321274.25989 & 4.77 & 0.076 & 0.183 & 0.123 \\
\hline P18 & 9908776.24667 & 321243.32862 & 6.91 & 0.147 & 0.347 & 0.192 \\
\hline P19 & 9908806.94929 & 321212.39734 & 4.93 & 0.035 & 0.108 & 0.063 \\
\hline P20 & 9908837.65192 & 321181.46607 & 5.46 & 0.067 & 0.180 & 0.143 \\
\hline P21 & 9883304.08415 & 304033.68820 & 3.86 & 0.314 & 0.558 & 0.301 \\
\hline P22 & 9882290.24433 & 303755.99155 & 26.99 & 0.314 & 0.558 & 0.301 \\
\hline P23 & 9903245.43308 & 316422.29540 & 5.13 & 0.099 & 0.234 & 0.147 \\
\hline P24 & 9906439.97905 & 316668.26844 & 5.34 & 0.169 & 0.444 & 0.256 \\
\hline P25 & 9907054.67127 & 317564.66862 & 4.44 & 0.132 & 0.424 & 0.185 \\
\hline P26 & 9906687.36339 & 320625.80638 & 6.05 & 0.130 & 0.346 & 0.195 \\
\hline P27 & 9906533.73606 & 320502.19487 & 5.29 & 0.099 & 0.234 & 0.147 \\
\hline P28 & 9905735.43790 & 321213.65828 & 4.08 & 0.062 & 0.187 & 0.113 \\
\hline P29 & 9909083.26074 & 320903.09675 & 4.52 & 0.055 & 0.128 & 0.084 \\
\hline P30 & 9909113.96343 & 320872.16543 & 4.49 & 0.049 & 0.138 & 0.094 \\
\hline P31 & 9909144.65366 & 320810.31515 & 6.18 & 0.083 & 0.439 & 0.153 \\
\hline P32 & 9882628.71882 & 304776.13261 & 6.90 & 0.099 & 0.262 & 0.187 \\
\hline P33 & 9901402.18079 & 315742.89461 & 5.76 & 0.096 & 0.267 & 0.191 \\
\hline
\end{tabular}

where $Z i$ is the elevation of a point on the DEM; $Z t$ is the elevation of a point surveyed in the field; and $n$ is the number of tested points.

All images had a mean total residue smaller than half of the nominal resolution of the Standard images. The DEMs were generated from the GCPs and RADARSAT-1 Standard images 1 and 6 (descending) and 2 and 7 (ascending) using the RADARSAT Specific Model from the software PCI Geomatica 10 (2005).
The flowchart with the steps for generating and evaluating the RADARSAT-1 Standard DEMs is shown in Figure 3.

The S1, S2, S6 and S7 images in PIX format were imported into a Geomatica OrthoEngine project to generate the DEMs. To evaluate the influence of the speckle noise in the original images on the generated DEMs, the filter Enhanced Frost was used to remove the high frequency noise (speckle) while preserving the edges of the features (PCI Geomatics, 2005). 


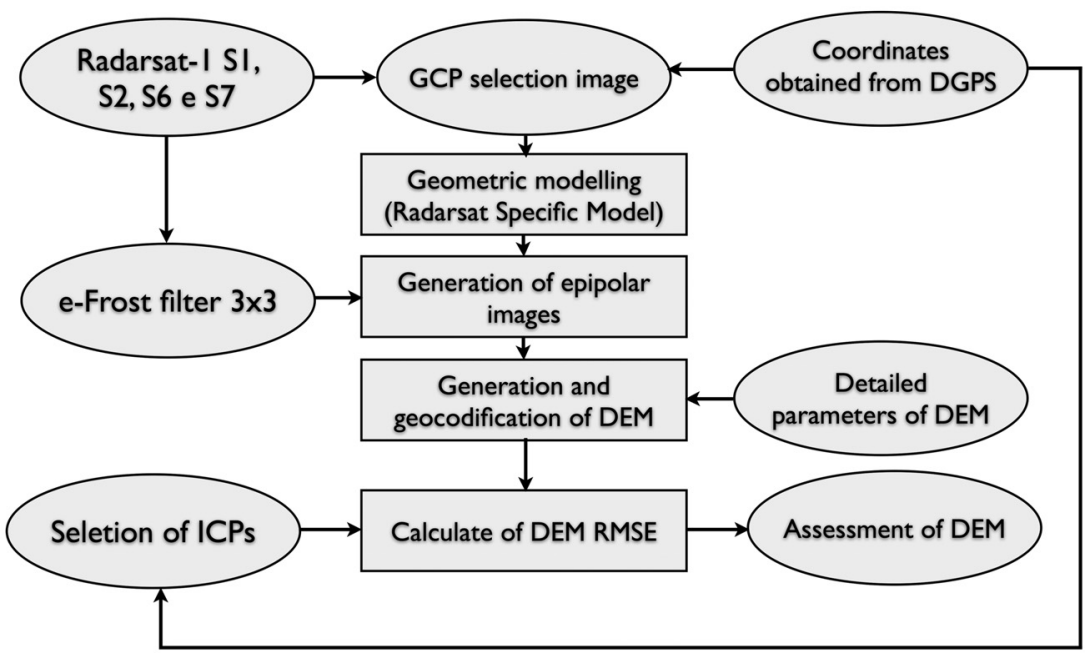

Figure 3 - Flowchart for the generation and evaluation of the RADARSAT-1 Standard DEMs.

Table 3 - Planimetric residues of 20 GCPs carried out in RADARSAT-1 S1 image, based on specific model.

\begin{tabular}{|c|c|c|c|c|c|c|}
\hline GCPs & $\begin{array}{c}\text { Mean } \\
\text { RMS error } \\
\text { (pixel) }\end{array}$ & $\begin{array}{c}\text { RMS } \\
\text { Error X } \\
\text { (pixel) }\end{array}$ & $\begin{array}{c}\text { RMS } \\
\text { Error Y } \\
\text { (pixel) }\end{array}$ & East & North & Alt Z \\
\hline G0005 & 0.78 & -0.53 & 0.57 & 316422.29540 & 9903245.4330 & 5.13 \\
G0007 & 0.73 & 0.59 & -0.43 & 317564.66862 & 9908745.5440 & 4.44 \\
G0049 & 0.69 & 0.38 & 0.58 & 293827,74500 & 9912547,1670 & 8.0 \\
G0006 & 0.46 & -0.36 & -0.28 & 316668.26844 & 9906439.9790 & 5.34 \\
G0050 & 0.40 & -0.14 & -0.38 & 291865,86800 & 9910982,7600 & 10 \\
G0024 & 0.36 & -0.13 & 0.34 & 304776.13261 & 9882628.7188 & 6.90 \\
G0040 & 0.34 & 0.15 & 0.31 & 300775,81000 & 9900455,1520 & 11 \\
G0034 & 0.24 & 0.24 & 0.03 & 331124,29600 & 9887813,8590 & 9 \\
G0055 & 0.24 & -0.21 & 0.12 & 306666,64000 & 9892866,4890 & 11 \\
G0010 & 0.19 & -0.17 & -0.09 & 313537,30100 & 9897438,5380 & 12 \\
G0036 & 0.18 & 0.11 & -0.14 & 318834,13100 & 9903964,5410 & 0 \\
G0013 & 0.17 & -0.14 & -0.10 & 321539,79400 & 9905409,0550 & 13 \\
G0065 & 0.16 & 0.09 & -0.13 & 307222,45300 & 9889898,7230 & 12 \\
G0004 & 0.15 & 0.06 & -0.14 & 315742.89461 & 9901402.1807 & 5.76 \\
G0053 & 0.15 & -0.11 & -0.10 & 347810,92800 & 9882462,0590 & 11 \\
G0048 & 0.14 & -0.08 & -0.12 & 349187,84800 & 9887981,1610 & 9 \\
G0011 & 0.12 & 0.09 & -0.08 & 357785,82500 & 9887825,3830 & 9 \\
G0028 & 0.11 & 0.07 & -0.08 & 359081,22800 & 9892850,4210 & 0 \\
G0050 & 0.09 & 0.02 & 0.08 & 334659,54000 & 9896609,2450 & 5 \\
G0009 & 0.06 & 0.06 & 0.02 & 305271,19400 & 9890951,6150 & 27 \\
\hline
\end{tabular}

RMS: 0.37 Pixel (4.62 m); XRMS: 0.25 Pixel (3.12 m); YRMS: 0.27 Pixel (3.34 m). 


Table 4 - Residual and RMS errors obtained for each RADARSAT-1 Standard
\begin{tabular}{|c|c|c|}
\hline Image & $\begin{array}{c}\text { Mean residual error } \\
\text { (pixel/metro) }\end{array}$ & Mean RMS error \\
\hline RADARSAT-1 S1 & $(0.28 / 3.6)$ & $(0.37 / 4.62)$ \\
RADARSAT-1 S2 & $(0.21 / 2.62)$ & $(0.30 / 3.75)$ \\
RADARSAT-1 S6 & $(0.35 / 4.37)$ & $(0.42 / 5.25)$ \\
RADARSAT-1 S7 & $(0.39 / 4.88)$ & $(0.47 / 5.88)$ \\
\hline
\end{tabular}

Twenty GCPs were monoscopically identified on the images, and mathematical modeling was conducted using the RADARSAT Specific Model, which considers the position and orientation of the sensor at the time of image acquisition and use of GCPs. The next stage of the process involved the transformation of two images into a single scene with an epipolar geometry (Lee \& Park, 2002). Thus, raw epipolar RADARSAT images with Enhanced Frost $3 \times 3$ filtering were generated.

Absolute DEMs were generated from the epipolar images with the following parameters:

- minimum elevation: 0 meters;

- maximum elevation: 200 meters;

- medium detail; and

- sampling factor of 2 (corresponding to 25 meters).

After the generation of RADARSAT DEMs, the geocoding process (georeferencing) of the DEM was performed.

\section{Statistical analysis}

The cartographic community uses linear error criterion as probabilistic confidence interval to estimate the altimetric accuracy (Toutin, 1997). A linear error designation of $90 \%$ (LE90) is used to quantify the elevation error of the DEM in relation to the real elevation measurements. An LE90 value of 20 meters indicates that $90 \%$ of the DEM pixels show a variation in elevation in relation to the "real elevation" of 20 meters or less. The following relationships are used in the calculation of the LE90:

$$
\begin{aligned}
\text { LE90 } & =1.6449 \times R M S \\
R M S & =\sqrt{(Z F-Z D G P S) 2 / N-1}
\end{aligned}
$$

where $Z F$ is the elevation of ICPs in the image; $Z D G P S$ is the elevation of the corresponding ICPS measured in the field by DGPS; and $N$ is the number of ICPs considered. The constant value in LE90 (1.6449) is the tabulated value for the $90 \%$ probability of the normal distribution.

Topographic maps in Brazil must comply with the Cartographic Accuracy Standards (Padrão de Exatidão Cartográfica - PEC) established by the Brazilian Cartographic Commission (Comissão Nacional de Cartografia - CONCAR) and be planialtimetric accurate. The PEC is a statistical dispersion indicator relative to $90 \%$ probability that defines the accuracy of cartographic works. The $90 \%$ probability corresponds to 1.6449 times the standard error or standard deviation $(\mathrm{PEC}=1.6449 \times \mathrm{SD})$ according to law decree number 89817 on 20 June 1984, which established the regulatory instructions for the technical standards of the CONCAR. In this decree, the topographic maps are organized into $A, B$ and $C$ classes according to the planimetric and altimetric PEC criteria, which are considered equivalent to the expressions standarderror, standard deviation and mean square error. In calculating the altimetry accuracy, linear error criteria were used with a 90\% probability interval (Toutin, 1998). The altimetric PEC requirement from the Cartography Commission of Brazil was used for the classification of the altimetric map (Table 5).

Table 5 - Altimetric tolerance of validation GCPs considering $1 / 3$ of standard error.

\begin{tabular}{|c|c|c|c|c|}
\hline Scale & $\begin{array}{c}\text { Equidistance } \\
\text { between } \\
\text { lines }\end{array}$ & $\begin{array}{c}1 / 3 \text { of } \\
\text { standard error } \\
\text { - Class A }\end{array}$ & $\begin{array}{c}1 / 3 \text { of } \\
\text { standard error } \\
\text { - Class B }\end{array}$ & $\begin{array}{c}1 / 3 \text { of } \\
\text { standard error } \\
\text { - Class C }\end{array}$ \\
\hline $1: 50,000$ & 20 & $2.22 \mathrm{~m}$ & $2.67 \mathrm{~m}$ & $3.33 \mathrm{~m}$ \\
$1: 100,000$ & 50 & $5.56 \mathrm{~m}$ & $6.67 \mathrm{~m}$ & $8.33 \mathrm{~m}$ \\
$1: 250,000$ & 100 & $11.11 \mathrm{~m}$ & $13.33 \mathrm{~m}$ & $16.67 \mathrm{~m}$ \\
\hline
\end{tabular}

Source: Adapted from CONCAR IBGE (1984) - http://www.concar.ibge.gov.br. 


\section{RESULTS AND DISCUSSION}

\section{Absolute radargrammetric DEMs}

The correlation of images is the core process for the generation of DEMs, and it eliminates the need for human operators to identify homologous points in the stereopair. Figure 4 shows the pairs S6Des/S1Des, S2Asc/S1Des, S7Asc/S6Des, and S7Asc/S2Asc that were generated after digital image processing and illustrates the results of the correlation of the raw images with pre-recorded images (epipolar data).

The pair S6Des/S1Des showed a vertical parallax ratio value of 0.48 and intersection angle of $20^{\circ}$ and it was not able to generate an absolute DEM. The intersection angle is formed between the common area generated by the stereopair images and obtained by the differences between the images. The stereopair S7Asc/S6Des with a vertical parallax ratio of 1.99 and intersection angle of $87^{\circ}$ also did not generate a DEM. The stereopair S2Asc/S1Des showed a vertical parallax ratio of 4.31 and intersection angle of $47^{\circ}$ and was able to generate an absolute DEM. As a result of the radiometric and geometric disparities and insufficient intersection area between the images that constituted the pair S7Asc/S2Asc, the DEM was not generated. The DEMs extraction results are shown in Figure 5.

The overall absolute DEMs extraction results from the pairs S6Des/S1Des, S7Asc/S6Des, S7Asc/S2Asc and S2Asc/S1Des are shown in Figure 5. The pairs illustrated in Figures 5a and $5 b$ showed areas with no elevation information, which precluded the generation of a DEM and did not provide georeferencing. The pair shown in Figure $5 c$ did not generate a DEM. Only the pair shown in Figure $5 d$ generated a DEM in $99 \%$ of the study area. Figure 6 illustrates the DEM generated with the application of the ocean mask delineating the coastline.

Table 6 shows that for the altimetry criterion of the PEC, the corresponding standard error of 5.10 obtained by Eq. (3) classifies the altimetric map into class A for altimetry. Table 6 also provides an RMSE value of 9.49 in which $1 / 3$ of this value is equal to 3.16 ; this result places the altimetric map within the tolerance range of the 1:100,000 scale for class A according to Table 5 and generates contouring with intervals of $50 \mathrm{~m}$.

Toutin (1999) stated that there is no correlation between the intersection angle and VPR and LE90 results when establishing the accuracy of the DEM. The parameter that has a significant impact on accuracy is the type of relief. In addition, there should be a compromise between the geometric and radiometric disparities when selecting the RADARSAT-1 stereopairs for the generation of DEMs. A pair of images with opposite-side looks shows small radiometric disparities in areas of flat terrain with slopes that range between $0^{\circ}$ and $10^{\circ}$. The geometric disparity is one of the most important requirements for generation of DEMs.

The configuration of the DEM generated from the stereopair S2Asc/S1Des with elevation variations equal to or less than $8.39 \mathrm{~m}$ or relative to the "real elevation" is similar to the configuration suggested by Toutin (1999).

The altimetric map generated from the absolute DEM with S2Asc/S1Des with contouring intervals of $50 \mathrm{~m}$ is shown in Figure $7 \mathrm{a}$. Figure $7 \mathrm{~b}$ shows the map with $10 \mathrm{~m}, 20 \mathrm{~m}$ and $50 \mathrm{~m}$ contour lines. To determine the accuracy of the altimetric map, the digital elevation values were converted from an ellipsoidal surface (original DEM product) to a geoid surface by subtracting the geoid undulation values obtained for each point measured by the DGPS. The altimetric accuracy result (RMSE $=9.49 \mathrm{~m}$ ) of the absolute DEM in the study area is consistent with class A at a 1:100,000 scale. This result confirms the potential use of this type of DEM for altimetric mapping applications at a semi-detailed scale in the Amazon coastal region. However, it is worth noting that the altitude values obtained in mangrove areas refer to the height of the tree canopy.

\section{CONCLUSIONS}

The stereopairs obtained from the SAR images from RADARSAT-1 at opposite sides showed the best results. The pair S2Asc/S1Des proved to be more effective at depth enhancement without losing stereoscopic visibility because it had the intermediate intersection angle values $\left(47^{\circ}\right)$ and highest vertical parallax ratio (4.31) among the evaluated pairs. The altimetric accuracy results (RMSE $=9.49 \mathrm{~m}$ ) of the S2Asc/S1Des absolute radargrammetric DEM are consistent with class A of the Brazilian Cartography Accuracy Standards at a 1:100,000 scale and corresponds to a standard error of 5.10, which classifies the altimetric map as class A for altimetry.

Therefore, the RADARSAT-1 Standard images are a useful alternative for the production of absolute DEMs at the 1:100,000 scale in low relief areas on coastal plains. With the advent of the RADARSAT-2 in 2007, which provided images in Ultra-Fine mode (spatial resolution of $3 \times 3 \mathrm{~m}$ ), it is possible to use a much larger number of GCPs in the generation of DEMs (absolute) because of the ease of identifying the corresponding homologous field points in the image.

\section{ACKNOWLEDGEMENTS}

This research was supported by CAPES (Coordenação de Aperfeiçoamento de Pessoal de Nível Superior) and CNPq (Conselho Nacional de Desenvolvimento Científico e Tecnológico). 

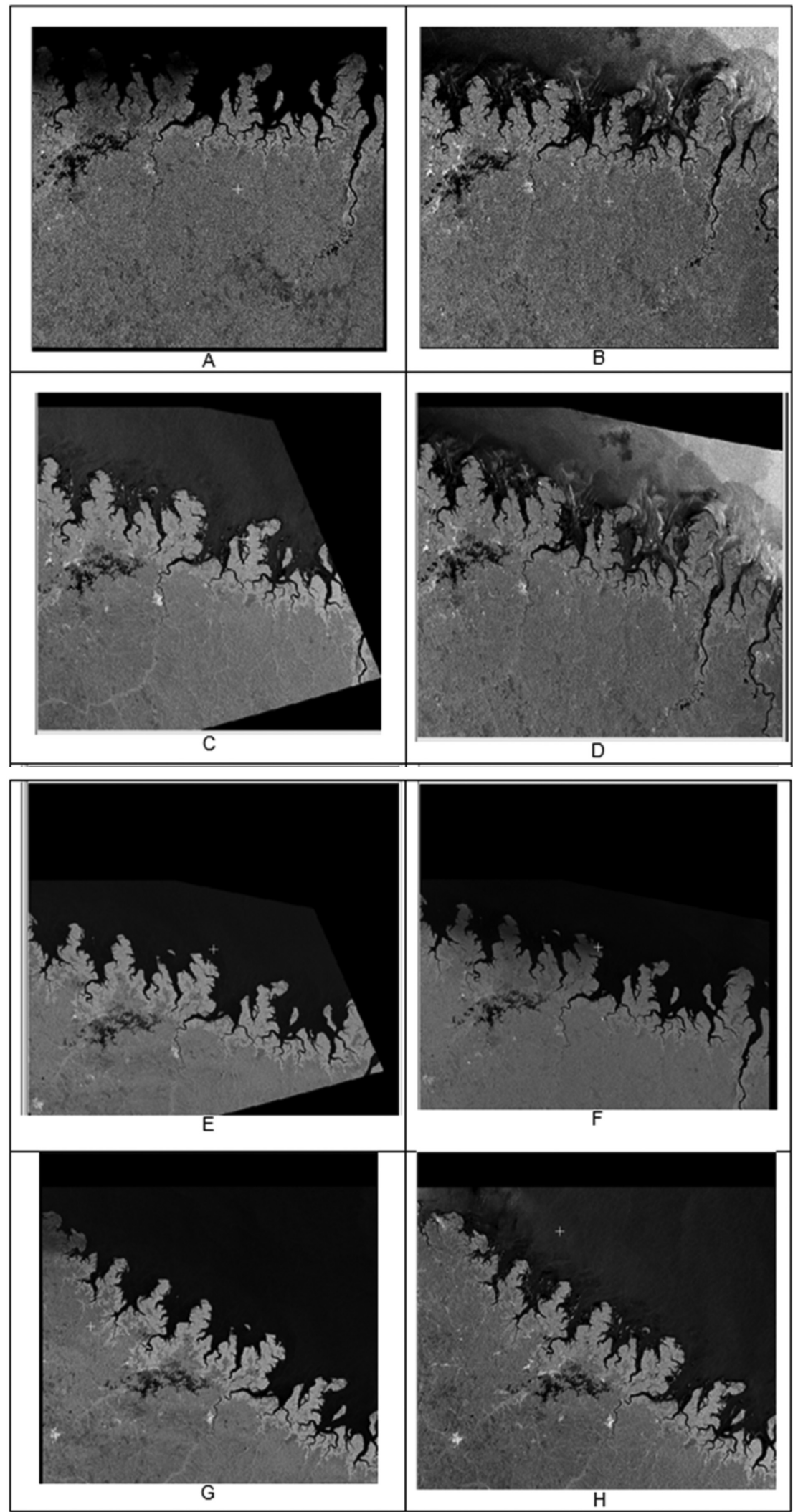

Figure 4 - Stereopairs generated after processing: S6Des/S1Des (A/B), S2Asc/S1Des (C/D), S7Asc/S6Des (E/F), and S7Asc/S2Asc (G/H). 


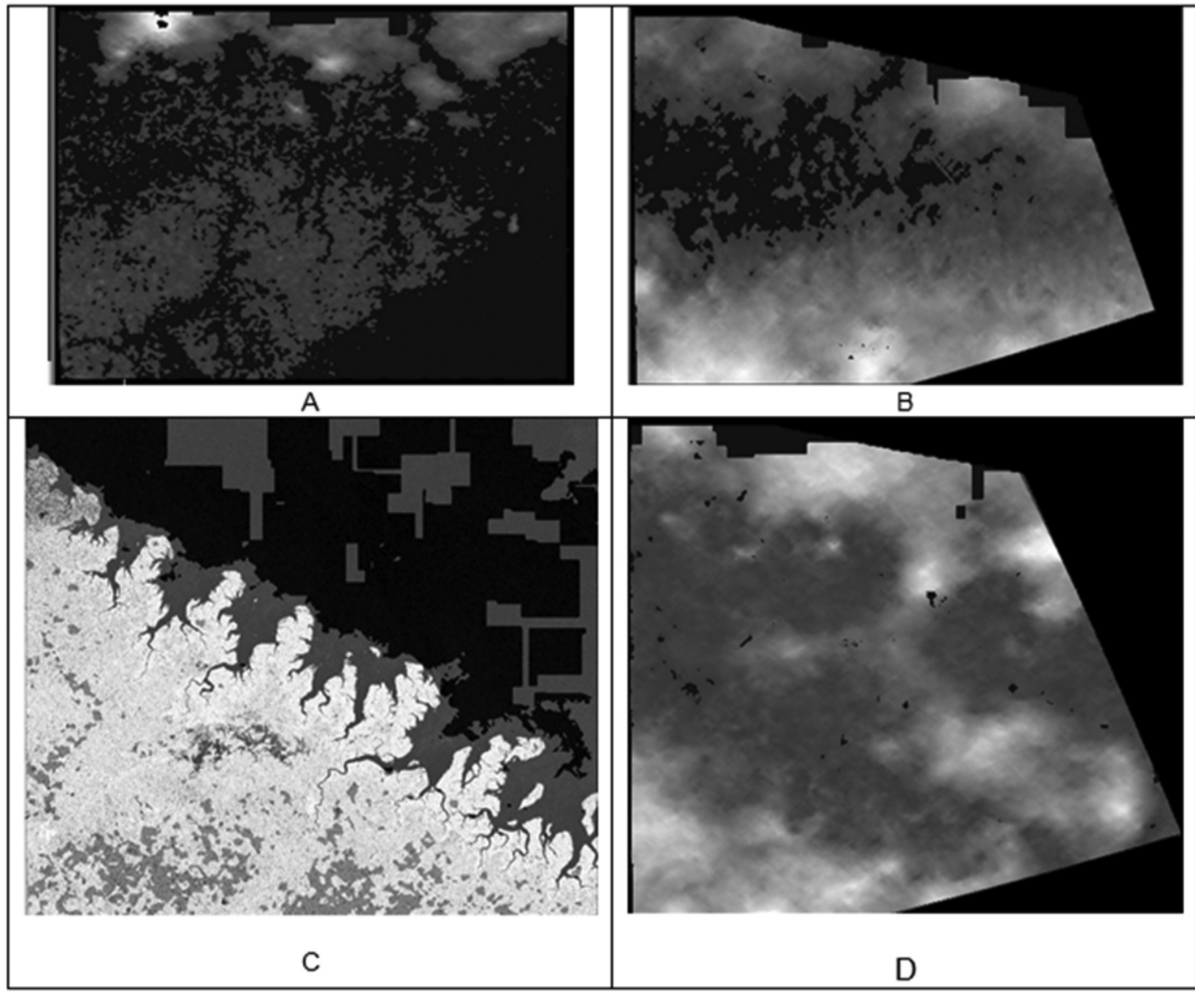

Figure 5 - Overall result of the extraction of absolute DEMs from pairs a) S6Des/S1Des, b) S7Asc/S6Des, c) S7Asc/S2Asc, and d) S2Asc/S1Des.

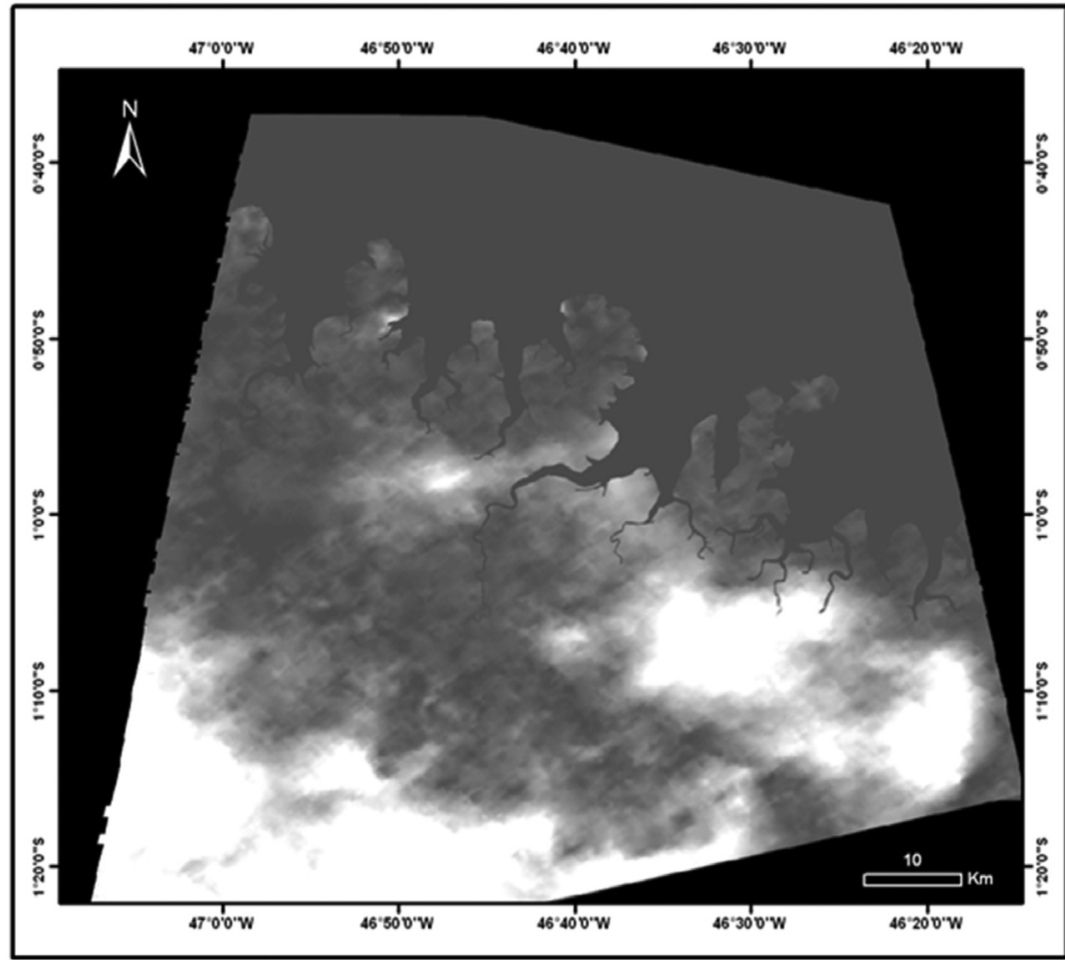

Figure 6 - Absolute DEM that was generated (S2Asc/S1Des), georeferenced and corrected for noise and imperfections; the ocean mask was applied to delineate the coastline. 
(A)

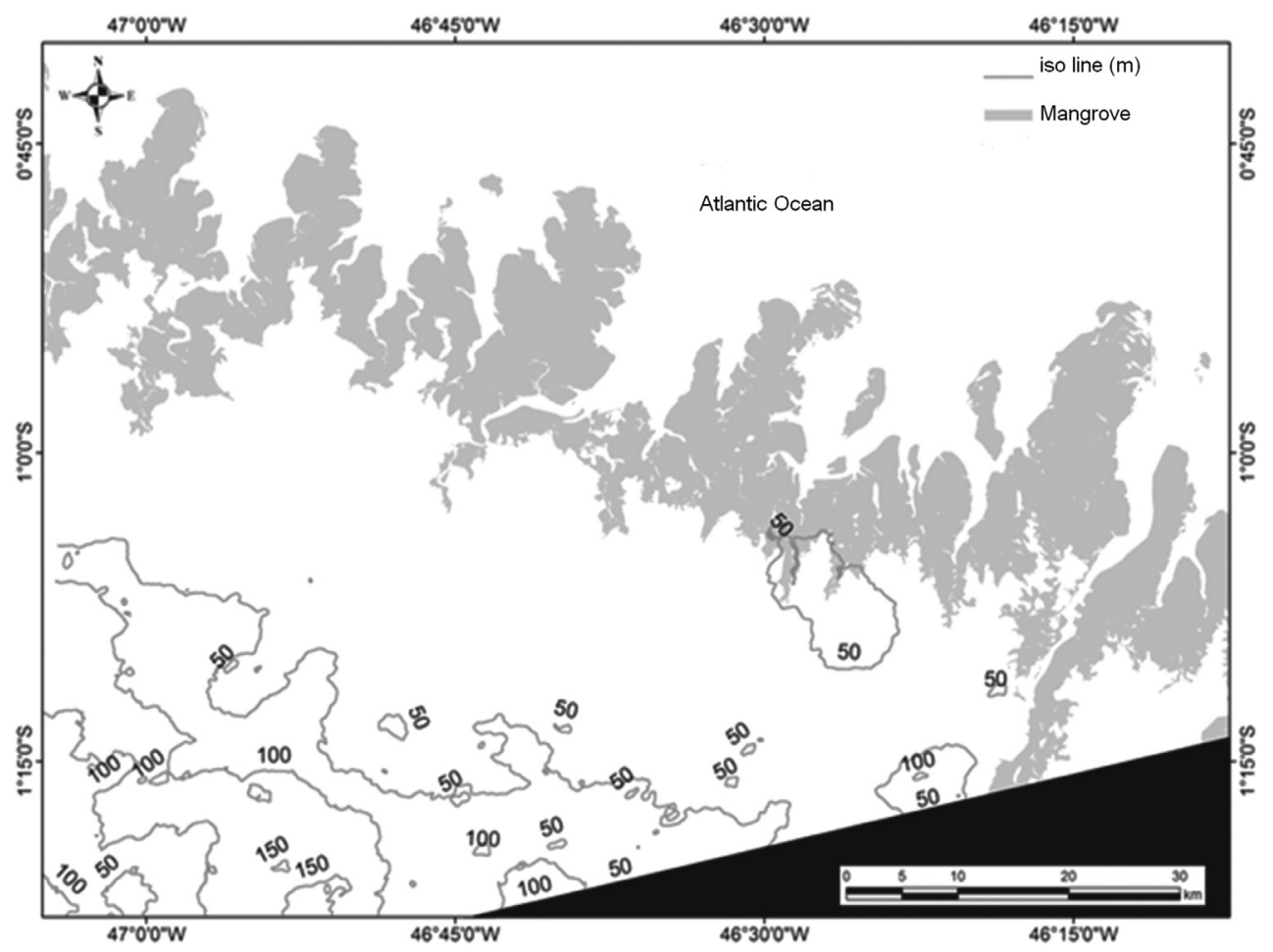

(B)

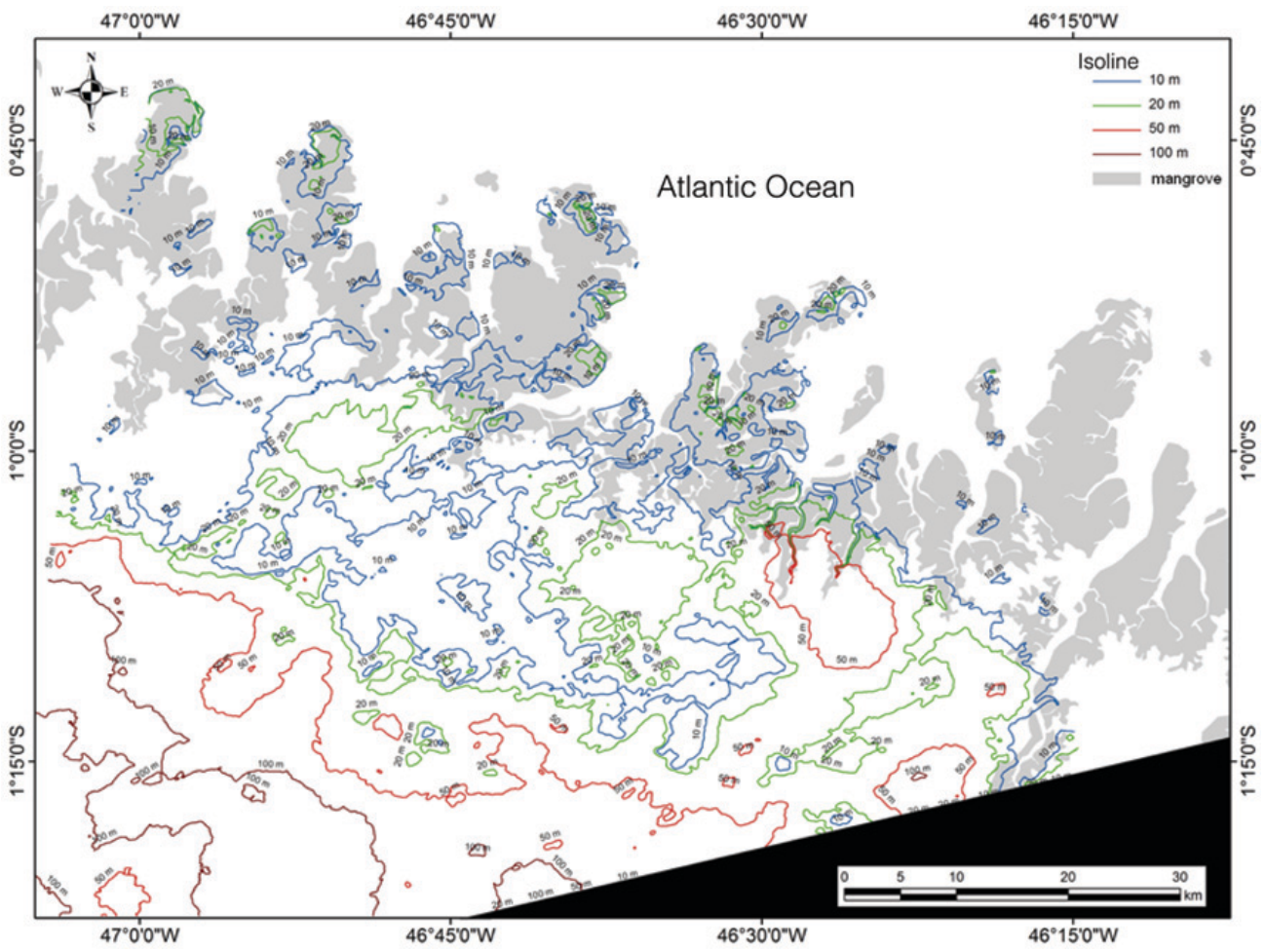

Figure 7 - Altimetric map generated from the absolute DEM with S2Asc/S1Des with $50 \mathrm{~m}$ contour lines (A) and $10 \mathrm{~m}, 20 \mathrm{~m}, 50 \mathrm{~m}$, $100 \mathrm{~m}$, and $150 \mathrm{~m}$ contour lines (B). Zone 23 South. 
Table 6 - Twenty-eight ICPs to validation of the scale of the mapping. Projection UTM, Zone 23 South and Datum SAD-69.

\begin{tabular}{|c|c|c|c|c|}
\hline ICPS & $\begin{array}{l}\text { UTM North } \\
\text { SAD-69 }\end{array}$ & $\begin{array}{l}\text { UTM East } \\
\text { SAD-69 }\end{array}$ & $\begin{array}{c}\text { Elevation of ICPS } \\
\text { measured in the field } \\
\text { (ZDGPS) }\end{array}$ & $\begin{array}{c}\text { Elevation of ICPS } \\
\text { measured in the image } \\
(\mathrm{ZF})\end{array}$ \\
\hline P01 & 9907947.14004 & 321738.36544 & 5.41 & 1 \\
\hline P02 & 9907977.84252 & 321707.43421 & 5.52 & 0 \\
\hline P03 & 9908008.55756 & 321707.42173 & 6.94 & 1 \\
\hline P04 & 9908039.24750 & 321645.57175 & 7.60 & 4 \\
\hline P05* & 9908131.38012 & 321614.61557 & 6.74 & 4 \\
\hline P06 & 9906439.97905 & 316668.26844 & 5.13 & 0 \\
\hline P07 & 9906687.36339 & 320625.80638 & 6.05 & 7 \\
\hline P08* & 9908346.34796 & 321521.77204 & 6.30 & 5 \\
\hline P09 & 9908407.77810 & 321521.74716 & 5.57 & 5 \\
\hline $\mathrm{P} 10^{*}$ & 9908469.19573 & 321490.80350 & 6.26 & 5 \\
\hline $\mathrm{P} 11^{*}$ & 9908530.61338 & 321459.85983 & 5.89 & 6 \\
\hline P12 & 9908530.58837 & 321398.02218 & 4.61 & 8 \\
\hline $\mathrm{P} 13^{*}$ & 9908592.00604 & 321367.07850 & 6.14 & 9 \\
\hline P14 & 9908622.72113 & 321367.06608 & 4.67 & 9 \\
\hline P15 & 9908653.42373 & 321336.13482 & 6.92 & 10 \\
\hline P16 & 9908684.12633 & 321305.20356 & 6.74 & 11 \\
\hline P17 & 9908745.54405 & 321274.25989 & 4.77 & 12 \\
\hline P18 & 9908776.24667 & 321243.32862 & 6.91 & 12 \\
\hline P19* & 9908806.94929 & 321212.39734 & 4.93 & 11 \\
\hline $\mathrm{P} 20^{*}$ & 9908837.65192 & 321181.46607 & 5.46 & 11 \\
\hline $\mathrm{P} 21^{*}$ & 9883304.08415 & 304033.68820 & 3.86 & 11 \\
\hline $\mathrm{P} 22^{*}$ & 9882290.24433 & 303755.99155 & 26.99 & 20 \\
\hline $\mathrm{P} 23^{*}$ & 9903245.43308 & 316422.29540 & 5.13 & 11 \\
\hline $\mathrm{P} 24$ * & 9906439.97905 & 316668.26844 & 5.34 & 0 \\
\hline $\mathrm{P} 25^{*}$ & 9907054.67127 & 317564.66862 & 4.44 & 7 \\
\hline P26 & 9906687.36339 & 320625.80638 & 6.05 & 19 \\
\hline P27 & 9906533.73606 & 320502.19487 & 5.29 & 22 \\
\hline $\mathrm{P} 28^{*}$ & 9905735.43790 & 321213.65828 & 4.08 & 9 \\
\hline \multirow{2}{*}{\multicolumn{3}{|c|}{$\begin{array}{l}\text { SUM of GCPS (ZDGPS) and (ZF) } \\
{ }^{\star} \text { SUM of ICPs (ZDGPS) and (ZF) }\end{array}$}} & 179.74 & 230 \\
\hline & & & 91.35 & 109 \\
\hline
\end{tabular}

The authors would like to thank the Canadian Space Agency for providing the RADARSAT-1 images and the technician Afonso Quaresma for his assistance in the field. The second and third authors would like to thank CNPq for granting the research productivity scholarship.

\section{REFERENCES}

FULLERTON JK, LEBERL F \& MARQUE RE. 1986. Opposite-side SAR image processing for stereo viewing. Photogram. Enginee. Rem. Sensing, 52: 1487-1498.
IBGE - Instituto Brasileiro de Geografia e Estatística. 2001. Mapa Índice Digital-Mapeamento Geral do Brasil. Primeira Edição, IBGE [Digital Index Map - General Mapping of Brazil]. First Edition, IBGE. CD-ROM.

LEE H \& PARK W. 2002. A new epipolarity model base on the simplified pushbroom sensor model. Joint International Symposium and Exhibition on Geospatial Theory, Processing, and Applications, Ottawa. Proceedings Ottawa: ISPRS Commission IV, 2002. WG IV/6. CD-ROM.

MONTEIRO MC, PEREIRA LCC \& OLIVEIRA SMO. 2009. Morphodynamic changes of a macrotidal sand beach in the Brazilian Amazon Coast (Ajuruteua - Pará). Journal of Coastal Research, SI 56: 103-107. 
MORAES BC, COSTA JMN \& COSTA ACL. 2005. Variação espacial e temporal da precipitação no estado do Pará [Spatial and temporal variation of precipitation in the state of Pará]. Acta Amazonica, 35: 207-214. NASCIMENTO Jr WR, SOUZA-FILHO PWM, PROISY C, LUCAS RM \& ROSENQVIST A. 2013. Mapping changes in the largest continuous Amazonian mangrove belt using object-based classification of multisensor satellite imagery. Estuarine, Coastal and Shelf Science, 117: 83-93.

OLIVEIRA CG, PARADELLA WR \& SILVA AQ. 2011a. Assessment of radargrammetric DSMs from TerraSAR-X Stripmap images in a mountainous relief area of the Amazon region. ISPRS Journal of Photogrammetry and Remote Sensing, 66: 67-72.

OLIVEIRA CG, PARADELLA WR, SANTOS AR \& ALBUQUERQUE PCG. 2011b. An Assessment of the Use of RADARSAT-2 for Detailed Topographic Mapping in a Tropical Semiarid Terrain of Brazil. Canadian Journal of Remote Sensing, 37: 472-483.

PARADELLAWR, CECARELLIICF, LUIZ S, OLIVEIRA CG, COTTINI CP \& OKIDA R. 2003. Produção de carta topográfica por estereoscopia de alta resolução do RADARSAT-1 integrada com dados TM-LANDSAT 5: uma avaliação para terrenos planos na Floresta Nacional de Tapajós (PA) [Production of topographic map by RADARSAT-1 high resolution stereoscopy integrated with TM-LANDSAT 5 data: an evaluation for flat terrains in the Tapajós National Forest (PA)]. Revista Brasileira de Geociências, 33(Supl. 2): 99-110.

PARADELLAWR, OLIVEIRA CG, LUIZ S, CECARELLIICF, COTTINI CP \& OKIDA R. 2005. Operational Use of RADARSAT-1 fine stereoscopy integrated with Landsat-5 thematic mapper data for cartographic application in the Brazilian Amazon. Canadian Journal of Remote Sensing, 31(2): 139-148.

PCI GEOMATICS. 2005. Geomatica User Manual. PCI geomatics, Version 10.0, Canada: $318 \mathrm{pp}$.

PEREIRA LCC, SILVA NIS, COSTA RM, ASP NE, COSTA KG \& VILACONCEJO A. 2012. Seasonal changes in oceanographic processes at an equatorial macrotidal beach in northern Brazil. Continental Shelf Research, 43: 95-106.

RABUS B, EINEDER M, ROTH A \& BAMLER R. 2003. The shuttle radar topography mission - a new class of digital elevation models acquired by spaceborne radar. ISPRS Journal of Photogrammetry and Remote Sensing, 57: 241-262.

RADARSAT International. 1995. RADARSAT Illuminated: your guide to products and services. Richmond, British Columbia CA. 60 pp.

SOUZA FILHO PWM. 2005. Costa de manguezais de macromaré da Amazônia: cenários morfológicos, mapeamento e quantificação de áreas usando dados de sensores remotos [Macrotidal mangrove coast of the Amazon: morphological scenarios, mapping and quantification of areas using data from remote sensors]. Brazilian Journal of Geophysics, 23(4): 427-435.

SOUZA FILHO PWM \& EL-ROBRINI M. 2000. Geomorphology of the Bragança coastal zone, northeastern Pará State. Revista Brasileira de Geociências, 30(3): 522-526.

SOUZA FILHO PWM, TOZZI HAM \& EL-ROBRINI M. 2003. Geomorphology, land-use and environmental hazards in Ajuruteua macrotidal study beach, northeastern Pará, Brazil. Journal of Coastal Research, SI 35: 580-589.

TOUTIN T. 1996. Opposite-side ERS-1 SAR stereo mapping over rolling topography. IEEE Trans. Geosci. Remote Sensing, 34: 543-549.

TOUTIN T. 1997. Évaluation de la géométre des images RADARSAT: premiers résultats. In: GER'97, Intern. Symp. Geomatics in the Era of RADARSAT, Ottawa, Canadá, Proceedings, CD-ROM.

TOUTIN T. 1998. Stereo RADARSAT for mapping applications. In: ADRO FINAL Symposium, Montreal, Canadá, Proceedings, CD-ROM.

TOUTIN T. 1999. RADARSAT for stereoscopy. Geomatics Info Magazine International, 13: 6-9.

TOUTIN T \& GRAY AL. 2000. State-of-the-art of extraction of elevation data using satellite SAR data. ISPRS Journal of Photogrammetry and Remote Sensing, 55: 13-33.

VAN DER SANDEN JJ \& ROSS SG. 2004. Applications Potential of RADARSAT-2: A Preview. Canada Centre for Remote Sensing, Report for Canadian Space Agency, Ottawa, Canada. 100 pp.

Recebido em 7 setembro, 2011 / Aceito em 5 fevereiro, 2014

Received on September 7, 2011 / Accepted on February 5, 2014 


\section{NOTES ABOUT THE AUTHORS}

Edson Adjair de Souza Pereira. Degree in Agronomic Engineering from the Faculdade de Ciências Agrárias do Pará (1978) with a specialization (1999) and master's degree in Geology (2007) from the Institute of Geosciences at the Universidade Federal do Pará - UFPA. Currently, is a professor at the Instituto Federal de Educação Científica e Tecnológica do Pará - IFPA and a Ph.D. student in the Institute of Geosciences at UFPA. Works in topography and remote sensing.

Pedro Walfir M. Souza-Filho. Degree in Geology at UFPA (1993) with specialization in Geology and Marine Geophysics from the Universidade Federal Fluminense - UFF (1993) and Ph.D. in Geology (Remote Sensing of Coastal Environments) at UFPA (2000). Has been professor at the School of Oceanography at the Institute of Geophysics at UFPA since 2002. Currently, is an associate researcher of the Vale Institute of Technology and has been a CNPq Research Productivity fellow since 2003.

Waldir Renato Paradella. Degree in Geology from the Institute of Geosciences at the Universidade de São Paulo - IG-USP(1973), master's degree in Remote Sensing from the Instituto Nacional de Pesquisas Espaciais - INPE (1976), Ph.D. in Geology from the IG-USP (1983) and Post-Doc supported by the CNPq (1988-1989) and CIDA - Canadian International Development Agency (1995-1996) at the Canada Centre for Remote Sensing (CCRS). Currently, is a senior researcher of the Division of Remote Sensing (Divisão de Sensoriamento Remoto - DSR) at INPE. Has experience in geosciences, with an emphasis on remote sensing applications (radar) and the geology and cartography of humid and semi-arid tropical environments.

Wilson da Rocha Nascimento Júnior. Bachelor in Geography at UFPA (2006) with master's degree in Geology (2011) in the Institute of Geosciences at UFPA. Currently, is a Ph.D. student in the same institute. 